\title{
Radiance と NewHASP を用いた外部・内部日射遮蔽物の最適化 \\ エネルギー性能・グレア・眺望性によるパレート解の導出 \\ OPTIMIZATION OF OUTSIDE AND INSIDE SUN SHADING DEVICES USING RADIANCE AND NEWHASP
}

Pareto optimal solution by energy usage, glare and view

\author{
大木 知佳子*1, 岡 本 俊 英 ${ }^{* 2}$, 只木 寿理恵 ${ }^{* 2}$, \\ 山本竜也 ${ }^{* 2}$, 相賀 洋 ${ }^{* 3}$, 吉澤 望*4 \\ Chikako OHKI, Toshihide OKAMOTO, Jyurie TADAKI, \\ Tatsuya YAMAMOTO, Hiroshi OHGA and Nozomu YOSHIZAWA
}

\begin{abstract}
Daylight harvesting is attracting attention from both energy saving and the viewpoint of improving the health and wellness of people in buildings. First, we made it possible to investigate the energy performance of outside and inside sun shadings in detail, by combining the annual calculation results by Radiance and NewHASP. Then, the evaluation module of visual environment, such as glare and view, was incorporated in the system using Radiance. Finally, multi-objective optimization simulation system is constructed for finding the optimal shape of the composite window system combining outside vertical louvers and inside venetian blind.
\end{abstract}

Keywords : Radiance, NewHASP, Thermal Load Calculation, Energy Simulation, Multi-objective Optimization Radiance，NewHASP，熱負荷計算，エネルギーシミュレーション，多目的最適化

\section{1. はじめに}

ZEB 化実現のために, 徹底した省エネルギーが求められている。 照明分野においても, 高効率な照明器具や各種センサによる照明制御 の採用のほか, 昼光の有効利用が省エネルギーのために重要と考えら れている。昼光利用によって人工照明にかかるエネルギー使用量を削 減することが可能となるが, 昼光の導入は同時に日射熱を取得するこ とになるため, 熱環境を含めて総合的にエネルギー性能を評価する必 要がある。

また昼光利用は, 省エネルギーだけでなく, 建物内で働く人々の健 康・快適性向上の観点からも, 注目されている。2019 年 3 月に発表 された欧州規格 ${ }^{1)}$ では, 昼光を確実に確保することを奨励するととも に, 十分に昼光を得るための昼光照度や開口部の目標值, 眺望性・グ レアの評価基準が定められた。

本研究では，光環境シミュレーションプログラム Radiance ${ }^{2) を}$ を利 用して算出した外部日射遮蔽物と内部日射遮蔽物 (ベネシャンブライ ンド（以下，ブラインド)）の複合日射特性と, 昼光利用時の照明制 御特性を，熱負荷計算プログラム NewHASP ${ }^{3)}$ に取り込み，年間時刻 別熱負荷を求めた。次に，この熱負荷を用いたビル用マルチシステム を想定した空調エネルギー使用量と, Radianceによって求めた昼光 利用による照明制御時の照明エネルギー使用量により, 空調・照明エ
ネルギー使用量を求めた。これらの一連の複合シミュレーションを行 なうプログラムを開発し, いろいろな形状の外部日射遮蔽物と内部日 射遮蔽物を併せ持つ室のエネルギー性能を計算することを可能にし た。

さらに，Radiance/OCTOPUS を利用することにより，エネルギー と視環境を目的関数として, 外部日射遮蔽物の垂直ルーバー・内部日 射遮蔽物のブラインドを組み合わせた複合空システムの形状設定を 求める多目的最適化システムを構築した。本論文では, シミュレーシ ヨンモデルと, 各種説明変数 (以下, パラメータ) の組合せを予め設 定して行なったスタディ（以下，パラメトリックスタディ）結果およ び多目的最適化計算結果について報告する。

\section{2. 既往研究と本研究の位置づけ}

熱負荷計算用空計算の既往研究として, ブラインドについては, 郡 ら ${ }^{4)}$ の提案する日射熱取得率と熱貫流率等を用いる簡易な計算法が 利用されてきた。詳細な計算法としては，吉澤ら ${ }^{5)}$ が， Radianceを 利用し, 入射角により変化するガラス光学特性の近似式とブラインド 光学特性のプロファイル角別データを用意し，これを用いて多重反射 と空熱平衡を時々刻々解く方法を提示した。また, 武田ら ${ }^{6)}$ は, ブラ インド設置時の光学特性をRadianceで求めて熱負荷計算プログラム

\footnotetext{
*1 (株)大林組

東京理科大学理工学研究科建築学専攻 博士後期課程

*2 東京理科大学理工学研究科建築学専攻修士課程

*3 侏)大林組 博士 (工学)

*4 東京理科大学理工学部建築学科 教授. 博士 (工学)
}

Obayashi Corporation /

Grad. Student, Dept. of Architecture, Tokyo University of Science

Grad. Student, Dept. of Architecture, Tokyo University of Science Obayashi Corporation, Dr.Eng.

Prof., Dept. of Architecture, Tokyo University of Science, Dr.Eng. 
$\mathrm{LESCOM}^{7)}$ に組込み, 1 分間隔の各種内ブラインド制御による年間冷 暖房負荷計算を行った。そして, 筆者ら ${ }^{8}$ は, BIM による 3 次元モ デルを用いて, 光環境シミュレーションプログラム Radianceにより 外部日射遮蔽物の日射遮蔽性能および昼光利用による照明制御時の 照明エネルギー使用量を求め, その日射遮蔽性能を熱負荷計算プログ ラム NewHASP3)に取り込んで求めた年間時刻別熱負荷から空調エ ネルギー使用量を求める一連の複合シミュレーションシステムを開 発し, 各種外部日射遮蔽物のエネルギー性能を評価できるようにした。 Lee ら ${ }^{9}$ は, にRadiance を利用して EnergyPlus と連携し, 直射日 光による空面入射日射量を求めた。

しかしながら, 外部日射遮蔽物と内部日射遮蔽物を併せ持つ空間に おける昼光利用の効果について, 照明エネルギー使用量, 熱負荷, 空 調エネルギー使用量を総合的に評価した報告はまだない。

外部・内部日射遮蔽物に関する最適化計算の既往研究として, Ma $\operatorname{nzan}^{10)}$ らは, 水平庇の設置高さ庇の長さ, 角度, 空方の離れを変数 として, 空調・照明エネルギー使用量を最小とする単目的最適化計

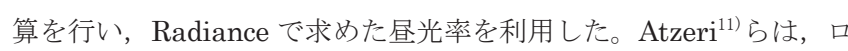
ールスクリーンと様々なガラスを組み合わせて, EnergyPlus を利 用して PMV (Predicted Mean Vote), DGI (Daylight Glare Ind $\mathrm{ex})$, 空調・照明エネルギー量を計算した。今田ら ${ }^{12)}$ は, DIVA（R hinoceros の日照シミュレーション用プラグイン) による年間昼光 シミュレーションを利用して, トップライトに設置する採光ルーバ 一の形状を変数とし, DA (Daylight Autonomy) ・ 空調エネルギ 一消費・材料費を目的関数とする最適化計算を, アルゴリズムエデ イタ Grasshopper と多目的最適化プラグインソフト OCTOPUS を 使用して行った。和田ら ${ }^{13)}$ は, 夏季の直射光と天空光を効果的に制 御するルーバーを検討するために, ルーバーのスラット形状を均等 に分割した位置の奥行きの長さを変数とし, 天空率と直射光遮蔽率 を目的関数とする最適化計算を, 多目的最適化アルゴリズム (MOG A）を使用して行った。大木 ${ }^{14)}$, 佐藤ら ${ }^{15)}$ は, 西面ファサードの縦 ルーバーを対象に, 縦ルーバーの枚数・奥行・角度を変数とし, 空 面日射量・インテリアの昼光照度・眺望性・材料費を目的関数とし た多目的最適化計算を，遺伝的アルゴリズム（NSGA-II）によって 行った。そして, 原田ら ${ }^{16)}$ は, 学校教室における昼光利用型ファ业 ードの検討のために，ライトシェルフの断面形状と室内ルーバー形 状を変数とし, 空調・照明エネルギー使用量・代表時刻のグレアを 目的関数とした最適化計算を, アルゴリズムエディタ Grasshopper と最適化プラグインソフト Galapagos を使用して行った。

しかしながら, 外部日射遮蔽物之内部日射遮蔽物を併せ持つ空間 におけるエネルギー性能・グレア・眺望性の多目的最適化について の報告はまだない。

なお, 本研究の一部である外部・内部日射遮蔽物のエネルギー性能 評価に関する内容については 2019 年度日本建築学会大会 (北陸) 学 術講演 ${ }^{17)}$ にて, また多目的最適化については CIE (International Commission on Illumination) 2019 29TH Quadrennial Session at Washington $^{18)}$ で報告を行なっている。本論文は, 熱環境と光環境の 総合的な評価のため, 新たな解析結果を加えて作成したものである。

3. シミュレーション全体フロー

本研究で構築したエネルギー・グレア・眺望性を目的関数とした遮
蔽物の最適形状導出のための多目的最適化モデルの構成と全体フロ 一を Fig.1 に示す。Radiance による直達成分・拡散成分・調光率・ ブラインド透過率特性それぞれの計算モジュールを利用して, NewHASP で熱負荷を求め, ビル用マルチシミュレーションにより, 空調エネルギー使用量を求める。調光率計算モジュールは, 照明エネ ルギー使用量にも利用寸る。グレア計算モジュール, 眺望性計算モジ ユールにも，Radiance を利用する。

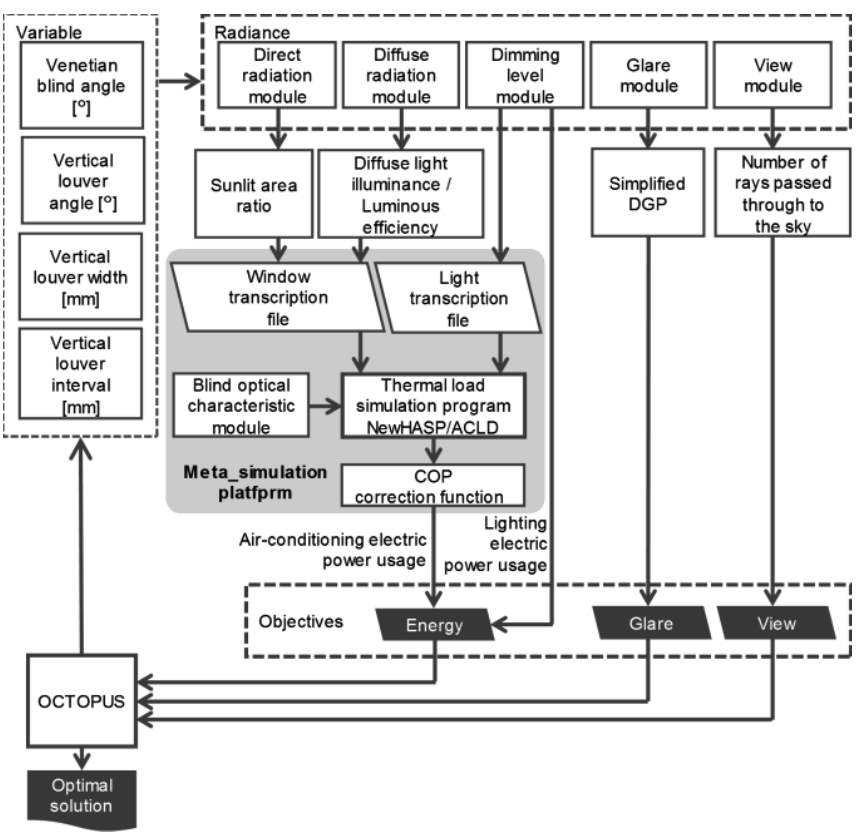

Fig.1 Configuration and flow of simulation model

\section{1 Radiance によるシミュレーション}

各計算モジュールを以下に説明する。なお直達成分・拡散成分・調 光率・ブラインド透過率特性計算モジュールは, 既に既報 8 で示した 手法であるが，以下ではその概略を記載する。

\section{1 . 1 直達成分計算モジュール}

空調エネルギー使用量を求めるためのガラス空標準日射熱取得計 算では, 日射熱取得を 3 つに分割して考えた ${ }^{8)}$ 。直達成分の計算には,

Radiance で求めた空の照度による空面日照面積率を利用した。天空 光による拡散成分の計算には, Radiance で求めた天空光の拡散成分 を, 地面と外部日射遮蔽物からの反射光の拡散成分には, Radiance で求めた拡散成分を用いた。これによって, 従来の NewHASP では 考慮できなかった, 外部日射遮蔽物からの反射光の拡散成分が, 正し く計算できるようになっている。

空面日照面積率の計算は, 光源に直射日光のみを設定し, 地物と外 部日射遮蔽物の反射率を $0 \%$ にした空面の照度を算出して主 ${ }^{1)}$, 照度 が 0 より大きい面積の比率を求めた。

\section{1.2 拡散成分計算モジュール}

天空光による空面照度の計算は, 光源に天空光のみを設定し, 地物 と外部日射遮蔽物の反射率を $0 \%$ とした時の空面平均照度を求め注 1$)$, EnergyPlus 用気象データ (以下, EPW) ${ }^{19)}$ の毎時の発光効率で除し て拡散成分とした。

地物反射光と外部日射遮蔽物反射光による空面照度の計算は, 光源 に直射日光と天空光を設定して, 地物と外部日射遮蔽物の反射率を入 
力した場合の照度と, 反射率を $0 \%$ とした場合の照度を求め注 ${ }^{1)}$, 差 分をとって地物と外部日射遮蔽物からの反射による照度とした。その 照度を EPW の毎時の発光効率で除して, 地物反射光と外部日射遮蔽 物反射光による拡散成分とした。

\section{1.3 調光率計算モジュール}

昼光の影響を考慮して，照度センサで感知している年間時刻別照 明調光率を求めた ${ }^{20)}$ 注1)。この調光率は, NewHASP における照明 熱取得計算および照明エネルギー使用量を求めるために利用した。

\section{1.4 グレア計算モジュール}

オフィスにおける執務者の快適性のために, 昼光によるグレアを評 価した。グレア指標には, 予測グレア感 PGSV (predicted Glare Sensation Vote) 21) や昼光グレア確率 DGP (Daylight Glare Probability）22)等の指標がある。PGSV は, 昼光照明による不快グレ アを予測, 評価する指標であり, 日本のオープンプランオフィスの空 の大きさに適している ${ }^{21)}$ 。DGP は, 昼光による眩しさを不快と感じ る人の割合を表し, simplified DGP は, 視点位置の鉛直面照度によ って簡易に評価することができるため, ファサードや遮蔽物の年間評 価に適している ${ }^{22)}$ 。今回は, 部屋の代表点における鉛直面照度を, Radianceによる年間計算によって算出し, simplified DGP を利用し てグレアを評価した。

\section{1.5 眺望性計算モジュール}

Radiance の rtrace コマンドを使用して, Fig.2 に示すように, あ る視点位置において視線方向ベクトルからの光線を追跡し, 到達した 対象面が天空や, 地面, 遮蔽物といった要素のいずれかであるかをピ クセルごとに出力した。今回は, 見た目の大きさとピクセル数の割合 が等しくなるという特徵を持つ等立体角射影方式を採用したため, 以 下の式(1)を用いて, 視線内 (180 度視野の円周画像) に占める天空の 割合を算出し，眺望性の指標とした。

$$
\mathrm{V}=\frac{\mathrm{N}}{\pi \mathrm{R}^{2}}
$$

$\mathrm{V} \quad$ : 眺望率 $[-]$

$\mathrm{N} \quad$ ： 空の要素を抽出したピクセル数 $[-]$

$\mathrm{R}$ ： 円周画像の半径に相当するピクセル数[-]

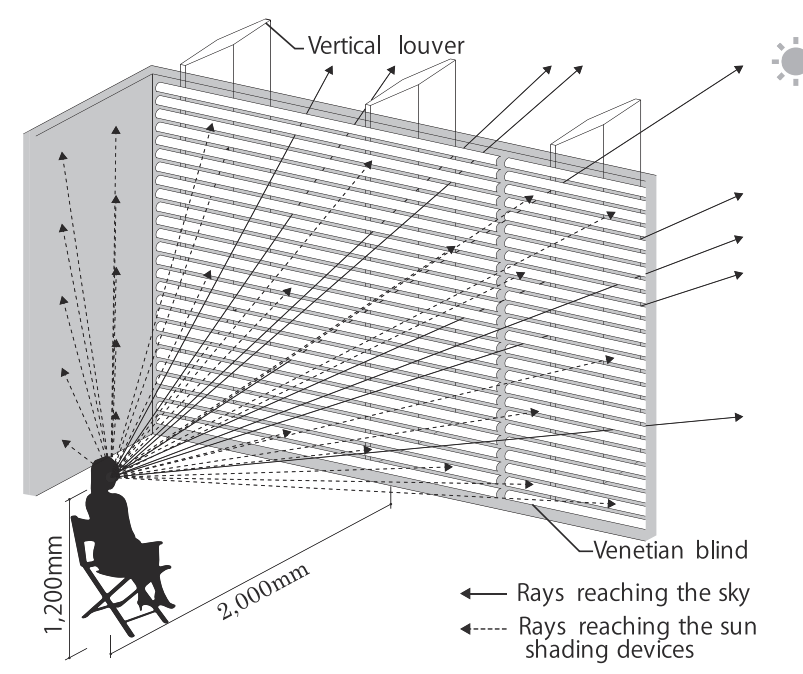

Fig.2 Radiance ray tracing
本研究では, 空面中央から室内側に $2 \mathrm{~m}$, 高さ $1.2 \mathrm{~m}$ の座標を視点 位置とし, 視点方向は空面と正対させた。解像度は, ブラインド幅を 通過する光線が十分に確保できるように設定した。外部日射遮蔽物之 して垂直ルーバー, 内部日射遮蔽物としてブラインドを設置した場合 における眺望性の関数を注 2 に示す。

\section{1.6 ブラインド透過率特性計算モジュール}

Fig. 3 に示寸ブラインドにプロファイル角 $0^{\circ} \sim 85^{\circ}$ ま $5^{\circ}$ 間隔に直 達日射を入射させ，スラット角を- $75^{\circ} ，-45^{\circ} ， 0^{\circ}, 45^{\circ}, 75^{\circ}$ に変化さ せた場合の，各放射束算出面の放射束を Radianceにより求め，ブラ インド単体の透過率 $\tau$, 反射率 $\rho$ を求めた ${ }^{23)}$ 。各スラット角における プロファイル角 $\varphi$ と透過率・反射率の関係を $\cos \varphi$ の 5 次式で近似 し, その近似式係数をスラット角 $\theta$ の近似式で示すことにより, 透過 率の関数 $\tau(\varphi, \theta)$ と反射率の関数 $\rho(\varphi, \theta)$ を求めた。なお, 本関 数は近似法によるものであり, 誤差は計算した 180 ケース中 165 ケ ースで $10 \%$ 以内であった。これらの関数で作成した透過率特性を Fig.4 に示す。

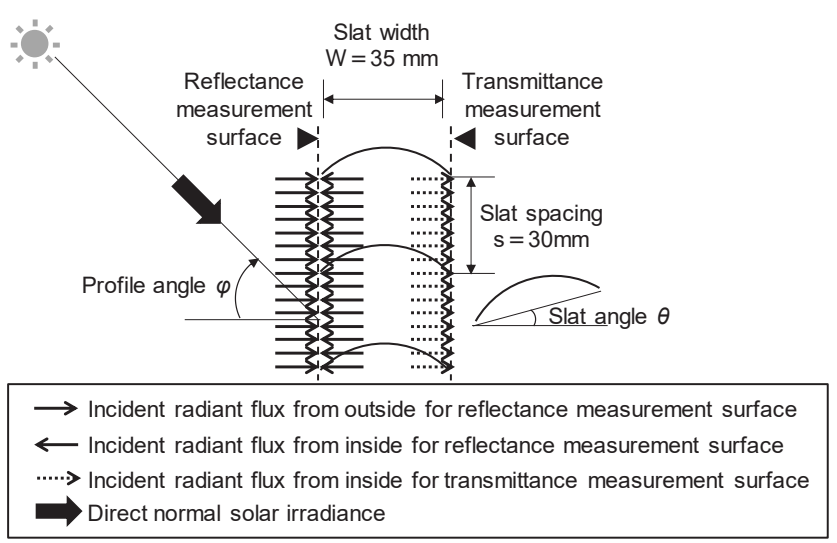

Fig.3 Radiance simulation blind function: $T(\varphi, \theta), \rho(\varphi, \theta)$
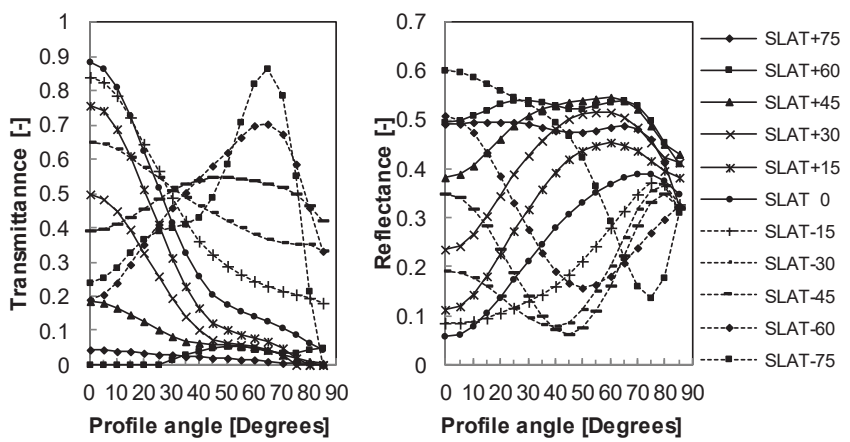

Fig.4 Blind transmittance function: $T(\varphi, \theta), \rho(\varphi, \theta)$

\section{2 NewHASPによるシミュレーション}

本研究では, 2004 年に空気調和・衛生工学会により開発された動 的熱負荷計算プログラム NewHASP に着目し, 従来の NewHASP に Radiance 計算結果を取り込み，年間熱負荷シミュレーションを行う 「NewHASP を核としたメタシミュレーション技術」232 24) 25)26)を利用 して, 年間熱負荷を求め, エネルギー性能を評価した。本技術は, 複 数のシミュレーション結果を NewHASP に取り込み，年間時刻別熱 負荷計算を行うためのメタ(上位の) シミュレーションモデルである。 それぞれのプログラムの変更を最小限にするため, データのやり取り 
は，双方のシミュレーション結果を書き写す専用時系列ファイル

(Transcription files) のみを介したバッチ処理（複数プログラムの 同時実行は行わない）とし，各プログラムの独立性を保っている。

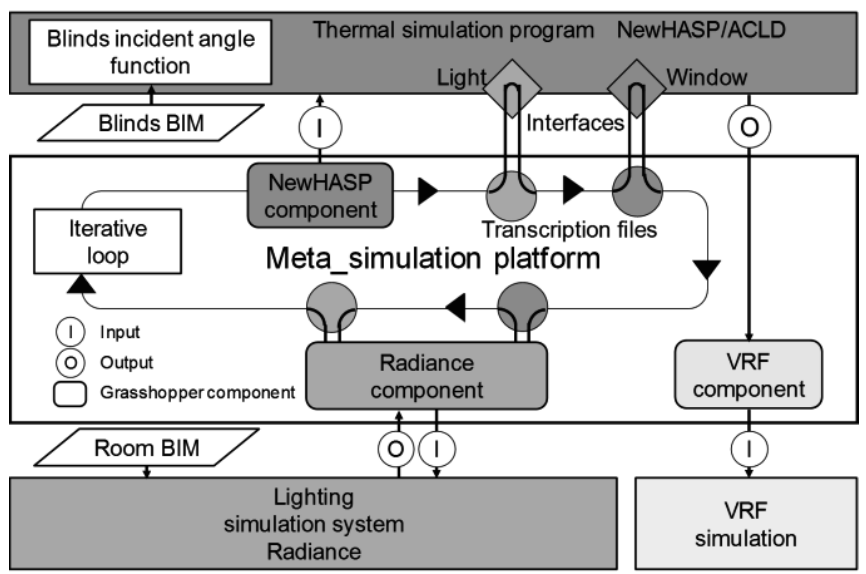

Fig.5 Meta_simulation platform

3. 3 ビル用マルチェネルギーシミュレーション

NewHASP による時刻別熱負荷を利用して, 空調エネルギー使用 量を求めるために, 外気温度と室内温度の入出力比関数 27 式を作成 した ${ }^{3}{ }^{3)}$ 。式(2)によって，時刻ごとの外気温度と室内吸込空気温度の 入出力比および部分負荷特性でビル用マルチの定格 COP （Coefficient Of Performance）を補正し，熱負荷を除した。

$$
\begin{aligned}
& C O P_{S}=C O P \times \frac{O_{o}}{I_{o}} \times \frac{O_{i}}{I_{i}} \\
& \mathrm{COP}_{S} \quad \vdots \text { 運転 COP [-] } \\
& \text { COP : 定格 COP [-] } \\
& I_{0} \quad \text { : 外気温度 (DB) 入力率 }[\%] \\
& O_{o}: \text { 外気温度 (WB) 出力率 [\%] } \\
& I_{i} \quad \text { : 室内吸込空気温度 (WB) 入力率 }[\%] \\
& O_{i} \quad \text { : 室内吸込空気温度 (DB) 出力率 [\%] }
\end{aligned}
$$

\section{4 多目的最適化}

本研究では, グラフィカルアルゴリズムエディタ Grasshopper28)を 利用して, 空調・照明エネルギー・グレア・眺望性の計算を実行した。 最適化計算は, 多目的遺伝的アルゴリズムを扱う Grasshopper のプ ラグインソフト OCTOPUS ${ }^{29)}$ を用い, 外部・内部日射遮蔽物に関す る 4 つのパラメータ（垂直ルーバーの角度, 幅, 間隔およびブライン

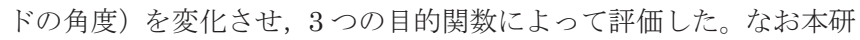
究の最終的な目標は, 固定・可動を含めた多種多様な条件のもとでの 外部・内部日射遮蔽物の最適化を検討することであるが，本報におい ては, その最初の取り組みとして, ルーバーやブラインドの角度は年 間を通して固定とした。

空調・照明エネルギーは, ビル用マルチシミュレーションによる空 調エネルギー使用量に, 調光率計算モジュールによる調光率と照明消 費電力密度による照明エネルギー使用量を合算した空調・照明エネル ギー使用量によって評価した。

グレアは, グレア計算モジュールによる部屋の代表点における simplified DGP が，閾值を超える割合で評価した。

眺望性は, 眺望性計算モジュールによる部屋の代表点における空の 見える割合で評価した。
4. シミュレーション事例

4. 1 シミュレーション対象建物

本研究で開発したシミュレーションシステムを利用して，Fig.6に 示す建物を対象として, 外部・内部日射遮蔽物のエネルギー性能，グ レア，眺望性を評価した。定格光束 3,334lm（発光効率 $100 \mathrm{~lm} / \mathrm{W}$ ) の LED 照明を想定し, 調光最大で $1,0001 x$ となるように 24 灯を $600 \mathrm{~mm}$ グリッド天井に配置し, 昼光利用により平均机上面照度が $7501 \mathrm{x}$ になるよう調光制御した ${ }^{20)}$ 。照度センサ位置は, 部屋の中央と し，グレアと眺望性は，ファサード面から $2,000 \mathrm{~mm}$ の位置を代表点 として評価した。計算条件を Table1に示す。
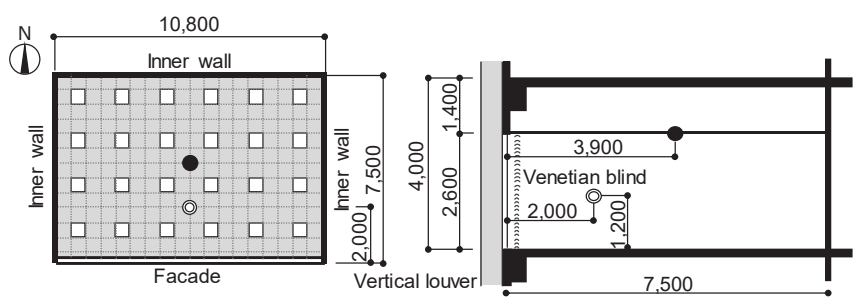

$\square$ : Luminaire $\bullet$ : llluminance sensor $\bigcirc$ : Glare and View point Fig.6 Room plan and section

Unit $[\mathrm{mm}]$

4. 2 シミュレーション対象外部・内部日射遮蔽物

シミュレーションの対象とした外部・内部日射遮蔽物の形状を

Fig.7, 8 に示す。

外部日射遮蔽物は垂直ルーバーとし, 角度 0 〜 $180^{\circ}$, 幅 220 $500 \mathrm{~mm}$, 間隔 1,000～2,000mm の範囲で任意に変化することとし た。内部日射遮蔽物はブラインドとし, 角度が $0,10,20,30,40,50$, $60,70^{\circ}$ のように $10^{\circ}$ 刻みに変化することとした。

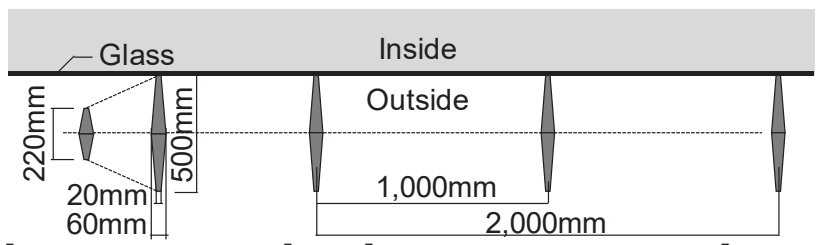

【Wide : 220 500mm】 【Interval : 1,000 2,000mm】

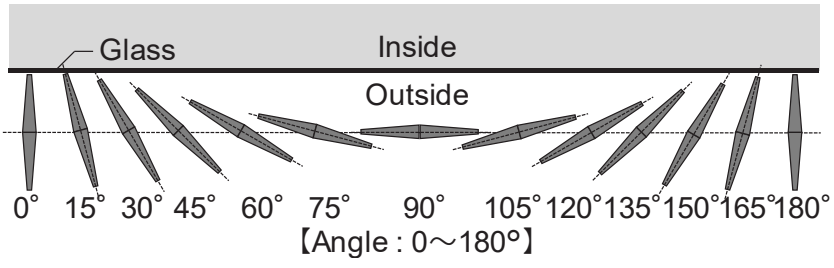

Fig.7 Detail of vertical louver

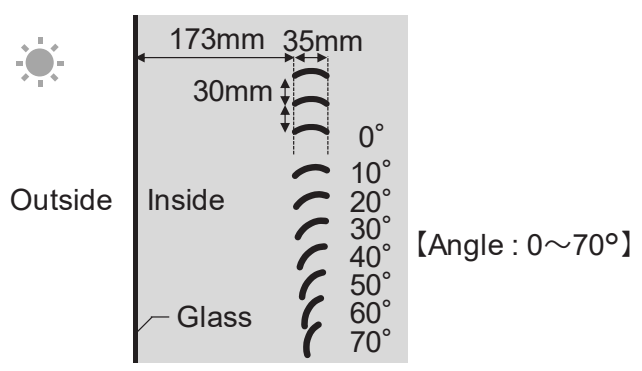

Fig.8 Detail of Venetian blind 


\section{3 パラメトリックスタディ結果}

多目的最適化を行うにあたり, 基本的なパラメータの挙動を調べる ために, Table 2 に示寸外部・内部日射遮蔽物条件における年間の空 調・照明エネルギー使用量, グレア, 眺望性を求めた。結果を Fig.9 $\sim$ Fig.12 に示す。

Table1 Calculation condition

\begin{tabular}{|c|c|c|c|}
\hline Building model & $\begin{array}{l}\text { Room usage } \\
\text { Orientation } \\
\text { Floor space } \\
\text { Ceiling Height } \\
\text { Floor above ground } \\
\text { level }\end{array}$ & \multicolumn{2}{|l|}{$\begin{array}{l}\text { Office } \\
\text { Facing south } \\
81 \mathrm{~m}^{2} \\
2.6 \mathrm{~m} \\
25.2 \mathrm{~m}\end{array}$} \\
\hline $\begin{array}{l}\text { Air } \\
\text { Conditioning } \\
\text { Zoning } \\
\end{array}$ & \multicolumn{3}{|c|}{1 zones(No distinction between perimeter and interior) } \\
\hline Weather data & Tokyo Hyakuri & \multicolumn{2}{|c|}{$\begin{array}{l}\text { EPW data (Weather Data for } \\
\text { EnergyPlus) }\end{array}$} \\
\hline $\begin{array}{l}\text { Season } \\
\text { Weekly } \\
\text { schedule } \\
\text { Special day }\end{array}$ & \multicolumn{3}{|c|}{$\begin{array}{l}\text { Summer season from June to September, winter months from } \\
\text { October to May (set as winter for the interim period ) } \\
\text { Weekday air conditioning, Saturdays-and-Sundays public } \\
\text { holidays non-air conditioning, special day non-air conditioning } \\
\text { Employment of energy conservation law standard room } \\
\text { calendar pattern }\end{array}$} \\
\hline Condition & $\begin{array}{l}\text { Air conditioning time } \\
\text { Room usage time } \\
\text { Amount of outside } \\
\text { air introduced } \\
\text { Pre-cooling } \\
\text { preheating time } \\
\text { Outside air cut }\end{array}$ & $\begin{array}{l}14 \text { hours } \\
13 \text { hours } \\
5 \mathrm{~m}^{3} / \mathrm{m}^{2} \mathrm{~h} \\
1 \text { hour }\end{array}$ & $\begin{array}{l}7 \mathrm{am}-9 \mathrm{pm} \\
8 \mathrm{am}-9 \mathrm{pm} \\
7 \mathrm{am}-8 \mathrm{am}\end{array}$ \\
\hline $\begin{array}{l}\text { Condition of } \\
\text { indoor } \\
\text { temperature } \\
\text { and humidity }\end{array}$ & $\begin{array}{l}\text { Summer : } 26^{\circ} \mathrm{C}, 60 \% \\
\text { Winter / intermediate }\end{array}$ & $\begin{array}{l}\text { less } \\
\text { riod : } 22 \text { to } 26^{\circ} \mathrm{C}\end{array}$ & $\%$ or more \\
\hline $\begin{array}{l}\text { Internal heat } \\
\text { and others }\end{array}$ & $\begin{array}{l}\text { Personnel density } \\
\text { Lighting density } \\
\text { Equipment density } \\
\text { (sensible heat only) }\end{array}$ & $\begin{array}{l}0.1 \text { persons } / \mathrm{m}^{2} \\
9.8 \mathrm{~W} / \mathrm{m}^{2} \\
12 \mathrm{~W} / \mathrm{m}^{2} \\
\\
\text { Summer : } 75 \% \\
\text { Winter / interm } \\
\text { Sensible heat : } \\
\text { Latent heat : } 40 \\
\text { Ventilation freq }\end{array}$ & $\begin{array}{l}\text { Weekday : 8am - } \\
\text { 9pm } \\
\text { Saturdays, } \\
\text { Sundays, and } \\
\text { holidays : off } \\
\text { Weekday : 8am - } \\
\text { 9pm } \\
\text { Saturdays, } \\
\text { Sundays, and } \\
\text { holidays : off } \\
\text { Weekday }: 8 \mathrm{am}- \\
9 \mathrm{pm} \\
\text { Weekday night, } \\
\text { Saturday and } \\
\text { Sunday all day } \\
25 \% \text { fever } \\
\\
\text { ate period } 75 \% \\
\mathrm{JJ} /\left(\mathrm{m}^{2} \cdot \mathrm{K}\right) \\
/\left(\mathrm{m}^{2} \cdot(\mathrm{g} / \mathrm{kg}(\mathrm{DA}))\right) \\
\mathrm{cy}: 0.2 \text { Times } / \mathrm{h} \\
\end{array}$ \\
\hline $\begin{array}{l}\text { Next room air- } \\
\text { conditioning } \\
\text { condition }\end{array}$ & Both floors & Air conditioning & \\
\hline Glass & $\begin{array}{l}\text { Side continuous } \\
\text { windows } \\
\text { Aperture ratio } \\
\text { Orientation } \\
\text { Ordinary } \\
\text { transparent single } \\
\text { plate } \\
\text { Transmittance } \\
\end{array}$ & $\begin{array}{l}28 \mathrm{~m}^{2} \\
65 \% \\
\text { South } \\
8 \mathrm{~mm} \\
87 \% \\
\end{array}$ & \\
\hline Outer wall & $\begin{array}{l}\text { South } \\
\text { Reflectance }\end{array}$ & $\begin{array}{l}15.1 \mathrm{~m}^{2} \\
50 \%\end{array}$ & \\
\hline Inner wall & Reflectance & $\begin{array}{l}25.8 \mathrm{~m}^{2} \\
50 \% \\
\end{array}$ & $\begin{array}{l}\text { Fully insulated } \\
\text { wall }\end{array}$ \\
\hline Floor & Reflectance & $\begin{array}{l}81 \mathrm{~m}^{2} \\
20 \% \\
\end{array}$ & \\
\hline Ceiling & Reflectance & $70 \%$ & \\
\hline Ground & Reflectance & $20 \%$ & \\
\hline $\begin{array}{l}\text { Outside and } \\
\text { inside } \\
\text { sun shading }\end{array}$ & Reflectance & $70 \%$ & \\
\hline $\begin{array}{l}\text { VRF system } \\
\text { COP }\end{array}$ & $\begin{array}{l}\text { Cooling }: 3.36 \\
\text { Heating }: 3.77\end{array}$ & & \\
\hline Glare & $\begin{array}{l}\text { simplified DGP thresh } \\
\text { Viewpoint height : FL }\end{array}$ & $\begin{array}{l}\mathrm{d}: 0.35 \\
1,200 \mathrm{~mm}\end{array}$ & \\
\hline View & Viewpoint height : FL & $1,200 \mathrm{~mm}$ & \\
\hline
\end{tabular}

Table2 Simulation cases

\begin{tabular}{ccccc}
\hline Case & $\begin{array}{c}\text { Venetian blind } \\
\text { angle }\left[^{\circ}\right]^{2}\end{array}$ & $\begin{array}{c}\text { Vertical louver } \\
\text { angle }\left[{ }^{\circ}\right]\end{array}$ & $\begin{array}{c}\text { Vertical louver } \\
\text { width }[\mathrm{mm}]\end{array}$ & $\begin{array}{c}\text { Vertical louver } \\
\text { interval }[\mathrm{mm}]\end{array}$ \\
\hline $\mathrm{a}$ & 0 & 0 & 220 & 1,000 \\
$\mathrm{~b}$ & 0 & 0 & 220 & 2,000 \\
$\mathrm{c}$ & 0 & 0 & 500 & 1,000 \\
$\mathrm{~d}$ & 0 & 0 & 500 & 2,000 \\
$\mathrm{e}$ & 0 & 90 & 220 & 1,000 \\
$\mathrm{f}$ & 0 & 90 & 220 & 2,000 \\
$\mathrm{~g}$ & 0 & 90 & 500 & 1,000 \\
$\mathrm{~h}$ & 0 & 90 & 500 & 2,000 \\
$\mathrm{i}$ & 70 & 0 & 220 & 1,000 \\
$\mathrm{j}$ & 70 & 0 & 220 & 2,000 \\
$\mathrm{k}$ & 70 & 0 & 500 & 1,000 \\
$\mathrm{l}$ & 70 & 0 & 500 & 2,000 \\
$\mathrm{~m}$ & 70 & 90 & 220 & 1,000 \\
$\mathrm{n}$ & 70 & 90 & 220 & 2,000 \\
$\mathrm{o}$ & 70 & 90 & 500 & 1,000 \\
$\mathrm{p}$ & 70 & 90 & 500 & 2,000 \\
\hline
\end{tabular}

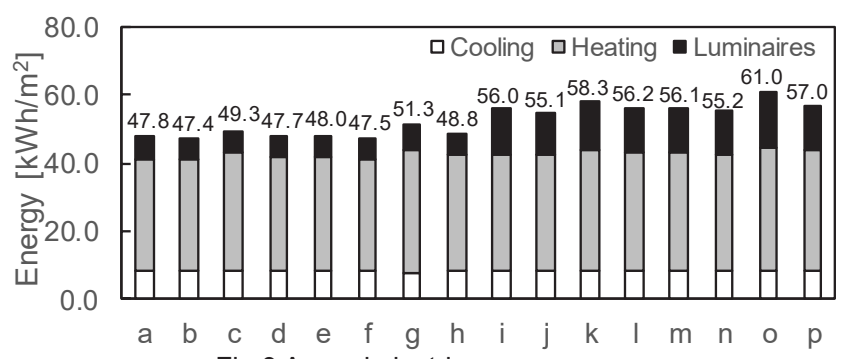
Fig.9 Annual electric power usage

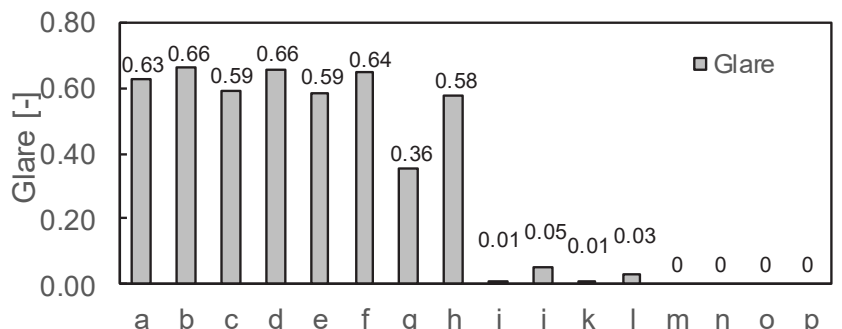
Fig.10 Glare

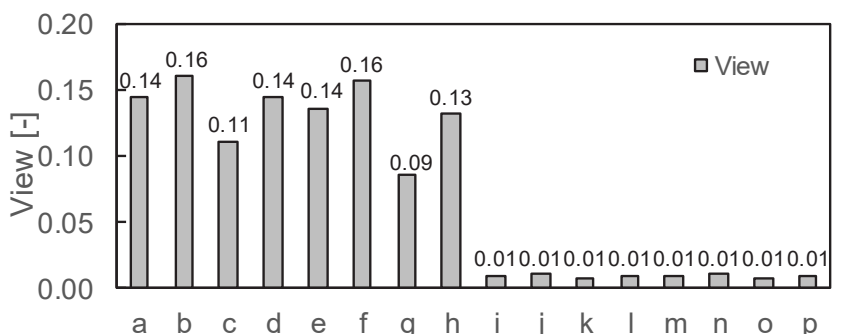
Fig. 11 View
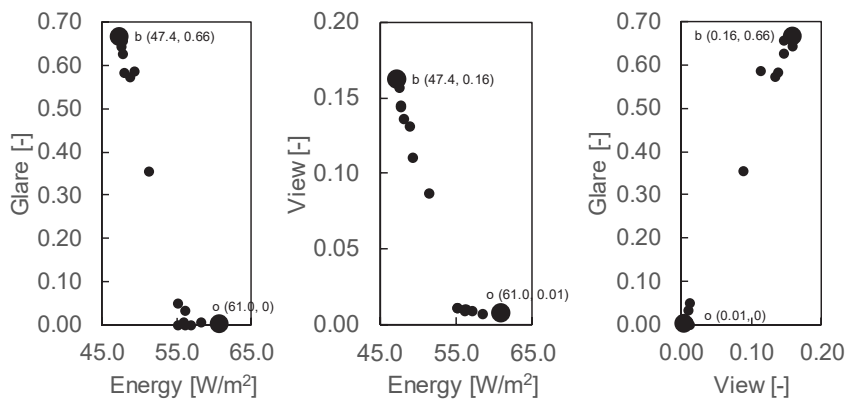

Fig.12 Energy, glare and view results

空調・照明エネルギー使用量は，ブラインドの角度は深く，垂直ル 一バーの角度は深く, 幅は長く, 間隔は狭くなる程, 大きくなる傾向 が見られた。これは, 気象条件を東京(百里)としたため, 冬の外気温 度が低く, 空調エネルギー使用量 (暖房) の占める割合が大きいため 
である注 4)。空調エネルギー使用量（冷房）は, 垂直ルーバーの幅は 短く, 間隔は広くなる程, 大きくなる傾向があり, ブラインド角度, 外ルーバー角度の影響はあまり受けていない。空調エネルギー使用量 (暖房) は, ブラインドの角度は深く, 垂直ルーバーの角度は深く, 幅は長く, 間隔は狭くなる程, 大きくなる傾向が見られた。照明エネ ルギー使用量は, ブラインドの角度は深く, 垂直ルーバーの幅は長く, 間隔は狭くなる程, 大きくなる傾向があり, 垂直ルーバーの角度の影 響はあまり受けていない。

グレアと眺望性は，ブラインドの角度は浅くなるほど大きくなり， 垂直ルーバーの角度は浅く, 幅は狭く, 間隔は広くなるほどやや大き い。グレアは, グレア光源からの発散光束に依存した視点位置の鉛直 面照度によって評価したためと考えられる。

また, 昼光利用による照明制御の有無と, 気象条件を東京（百里） から鹿児島に変えた場合における, 年間合計熱負荷と年間の空調・照 明エネルギー使用量を, ブラインドと垂直ルーバーの条件が最も開放 的な Case b と, 最も閉鎖的な Case o で比較した結果を Fig.13, 14 に示す。
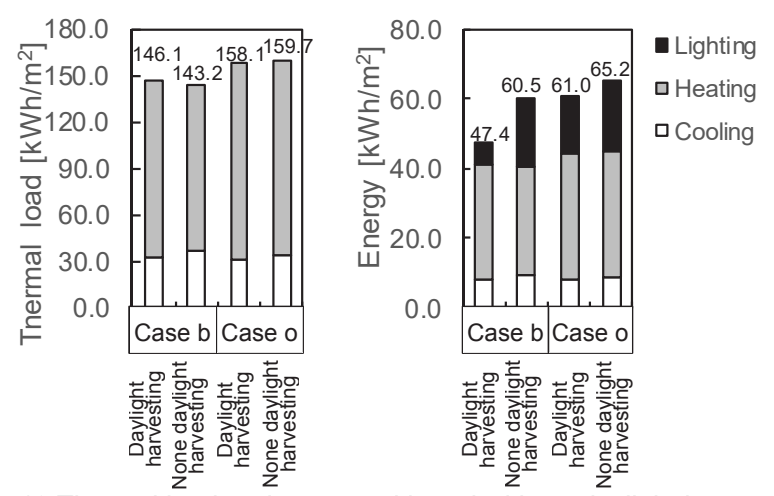

Fig.13 Thermal load and energy with and without daylight harvesting
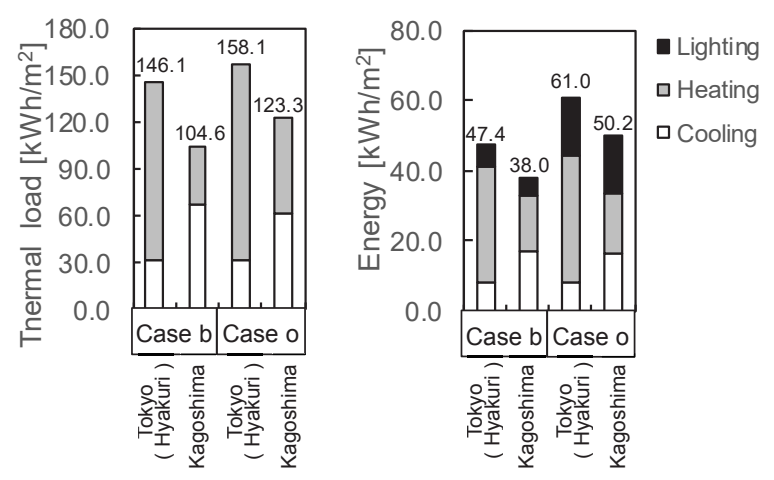

Fig.14 Thermal load and energy of Tokyo (Hyakuri) and Kagoshima

昼光利用による照明制御がある場合, 年間合計熱負荷は, Case b は やや大きく, Case o はやや小さいが, 照明制御なしと大きな差が見 られなかった。空調・照明エネルギー使用量は, Case b は昼光利用 の効果が大きく, 昼光利用による照明制御は, 照明エネルギー使用量 に対する効果が大きいことが示された。

気象条件を鹿児島とした場合は, 東京 (百里)に比べ, 年間合計熱 負荷は, 冷房負荷が増加するが, 暖房負荷が減少するため, Case b, Case o ともに鹿児島の方が小さくなった。鹿児島の空調・照明エネ ルギー使用量は, 空調エネルギー使用量 (冷房) が増加するが, 空調 エネルギー使用量 (暖房) が減少するので, Case b, Case o どちらの
場合も, 東京 (百里) より小さくなることが示された。また, 東京 (百 里), 鹿児島ともに，開放的な Case b の方が閉鎖的な Case o に比べ て空調・照明エネルギー使用量, 年間合計負荷ともに小さくなった。 これは, ブラインドを常に下ろした状態で比較しているため, 空調エ ネルギー使用量に差が生じにくいためと考えられる注5)。また, 今回 は, 空調と照明を合わせたエネルギー使用量で評価するため, 熱負荷 として外部・内部日射遮蔽物の影響を受けない外気負荷や潜熱負荷を 含めた装置全熱負荷を用いた。そのため, 空調エネルギー使用量の内, 変化しない部分が大きくなり, 差が小さくなった。

\section{4 多目的最適化計算の結果}

パラメトリックツール Grasshopper と多目的最適化プラグインソ フト OCTOPUS を使用したエネルギー・グレア・眺望性を目的関数 とする多目的最適化計算を行った。遺伝的アルゴリズムの計算条件と して, 一世代の個体数を 12 , 世代数を 10 , 突然変異率を 0.1 , 交差 率を 0.8 と設定し, アルゴリズムは $\mathrm{HypE}^{30)}$ を選択した。 HypE は, 進化計算による多目的最適化のアルゴリズムであり, パレートフロン 卜を近似する解への貢献度を算出して, 細やかに解を優劣づけするア プローチである。獲得した解集合が目的関数空間に作る超体積を評価 尺度とし, 值が大きい解集合ほどパレートフロントの近似性能が良好

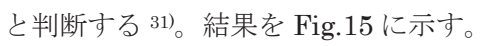

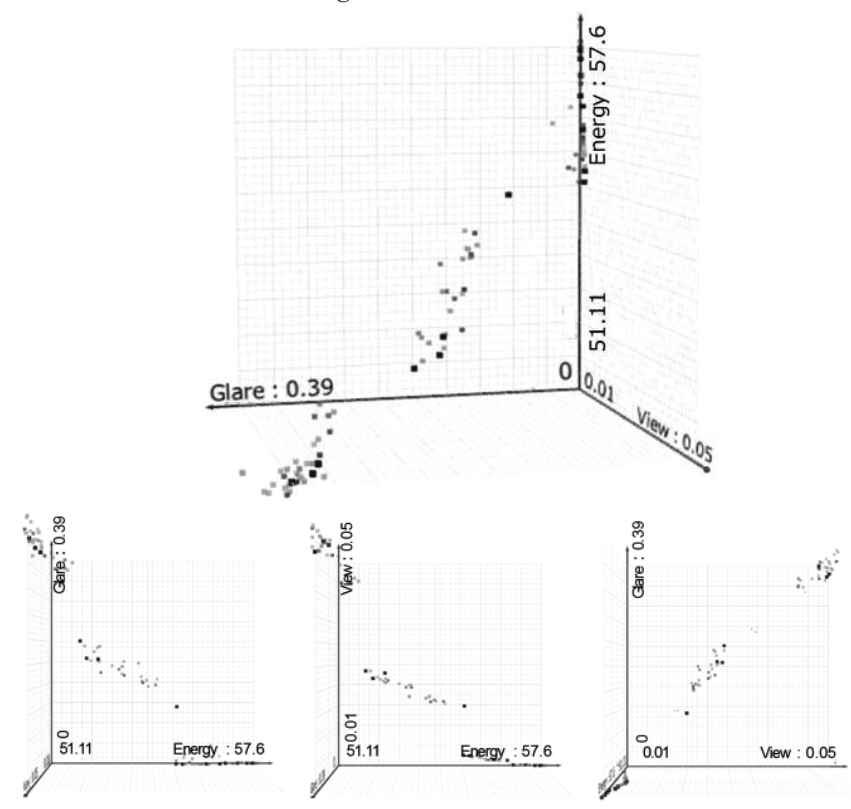

Fig.15 Pareto optimal solution

エネルギー・グレア・眺望性の結果をそれぞれの軸に表したパレー 卜最適解は, 空調・照明エネルギー使用量が大きいほどグレア, 眺望 性が小さく, 眺望性が高いほどグレアが大きくなっており, パラメト リックスタディ結果と傾向が一致した。グレアと眺望性の相関が高い ため, 曲面ではなく, 曲線状のパレート最適解が算出された。

今回の結果を見ると, エネルギーと眺望性を優先するならば, ブラ インド:角度 $0^{\circ}$, 垂直ルーバー: 角度 $0^{\circ}$ ・幅 $220 \mathrm{~mm}$ ・間隔 $2,000 \mathrm{~mm}$ が最適解であり, グレアを優先するならば, ブラインド : 角度 $70^{\circ}$, 垂直ルーバー: 角度 $90^{\circ}$ ・幅 $500 \mathrm{~mm}$ ・間隔 $1,000 \mathrm{~mm}$ が最適解とな っている。選好最適解としては， 3 つの目的関数のバランスをとり， 
ブラインド : 角度 $70^{\circ}$, 垂直ルーバー : 角度 $0^{\circ}$ ・幅 $220 \mathrm{~mm}$ ・間隔 $2,000 \mathrm{~mm}$ が採用できよう。

\section{5. まとめ}

本研究では, 光環境シミュレーションプログラム Radiance と熱負 荷シミュレーションプログラム NewHASP を組合せたメタシミュレ ーションプラットフォームを利用して, 外部日射遮蔽物と内部日射遮 蔽物を合わせた照明・空調エネルギーを評価した。また，エネルギー 性能評価の他に, Radiance を利用して求めたグレアと眺望性の評価 を加え, はじめに, グラフィカルアルゴリズムエディタ Grasshopper を利用して, エネルギー・グレア・眺望性の計算を実行し，基本的な パラメータの組合せにおける挙動を確認するために, パラメトリック スタディを行った。次に, 多目的遺伝的アルゴリズムを扱うプラグイ ンソフト OCTOPUS を用いた多目的最適化計算により, 外部・内部 日射遮蔽物に関する 4 つのパラメータ（垂直ルーバーの角度, 幅, 間 隔およびブラインドの角度)を変化させた場合の, 3 つの目的関数 (エ ネルギー,グレア, 眺望性) を評価し, 東京（百里）においては, 空 調・照明エネルギー使用量が大きいほどグレア, 眺望性が小さく, 眺 望性が高いほどグレアが小さいという曲線状のパレート最適解が得 られることを明らかにした。そして, パラメトリックスタディにおい て得られたエネルギー・グレア・眺望性の関係と, 多目的最適化計算 で得られたパレート最適解における目的関数 : エネルギー・グレア・ 眺望性の関係が一致したことを確認し, 多目的最適化計算が正しくな されており, 今後の複合空システムの形状設定に有用であることが明 らかになった。

グレアについて, 今回は代表する 1 点で評価したが, 複数点の平均 值をシミュレーションに組み込むことも可能である。

眺望性について, 欧州規格では, 空の水平角, 隣棟までの距離, そ して空・風景・地面が何層見えるかで評価している 1)。今回は簡易な 評価として, 代表点から見た空の割合を利用したが, 欧州規格に応じ た評価をシミュレーションモデルに組み込むことも可能である注6)。

本研究では, 代表的な外部日射遮蔽物である垂直ルーバーと, 代表 的な内部日射遮蔽物であるブラインドの年間固定角度における多目 的最適化計算を実行したが, 今後はブラインドを保護角制御した場合 や, 可動式の外部日射遮蔽物, そして曲面を含むより複雑な外部日射 遮蔽物の最適化計算にも適用していきたい。

\section{注}

注 1) Radiance 計算パラメータを以下に示す。

\begin{tabular}{cc} 
& Table A1 Radiance parameters \\
\hline Parameter & Name \\
\hline ab & ambient bounces \\
aa & ambient accuracy \\
ar & ambient resolution \\
as & ambient super-samples \\
ad & ambient divisions \\
lw & Limit the weight of each ray to a minimum \\
dc & direct certainty \\
dt & direct threshold \\
dj & direct jittering \\
st & specular sampling threshold \\
ss & specular sampling \\
e & the number of samples produced per Klems division \\
c & sample rays to accumulate \\
\hline
\end{tabular}

Table A2 Radiance parameter setting

\begin{tabular}{c|c|c|c|c|c|c|c|c|c|c|c|c|c}
\hline & ab & aa & ar & as & ad & lw & dc & dt & dj & st & ss & e & c \\
\hline $\begin{array}{c}\text { Direct radiation } \\
\text { Three phase method }\end{array}$ & 0 & 0.15 & 512 & 32768 & 65536 & $1.52 \mathrm{e}-5$ & 1 & 0 & 0 & 1 & 0 & MF: 6 & - \\
$\begin{array}{c}\text { Diffuse radiation } \\
\text { Three phase method } \\
\text { Dimming level }\end{array}$ & 0 & 0.15 & 512 & 32768 & 65536 & $1.52 \mathrm{e}-5$ & - & - & - & - & - & MF:1 & 1000 \\
Daylight Coefficient & 1 & 0.15 & 512 & 32768 & 65536 & $1.52 \mathrm{e}-5$ & - & - & - & - & - & MF:1 & - \\
$\begin{array}{c}\text { Glare } \\
\text { Daylight Coefficient }\end{array}$ & 6 & 0.15 & 512 & 256 & 512 & - & - & - & - & - & - & - & - \\
\hline
\end{tabular}

注 2) Fig.7, 8 に示す垂直ルーバー角度とブラインド角度別に求めた眺望性の 結果を Fig.A1 に示す。垂直ルーバー幅 $360 \mathrm{~mm}$ ，間隔 $1,500 \mathrm{~mm}$ とした。

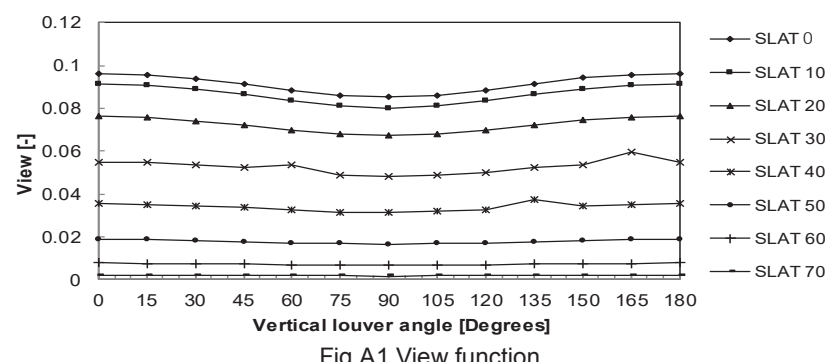

注 3) ビル用マルチ定格 COP 補正のための, 外気温度と室内温度の入出力比関 数式を Fig.A2〜A5 に示す。 $\left(\mathrm{R}^{2}\right.$ は全て 0.99 以上 $)$
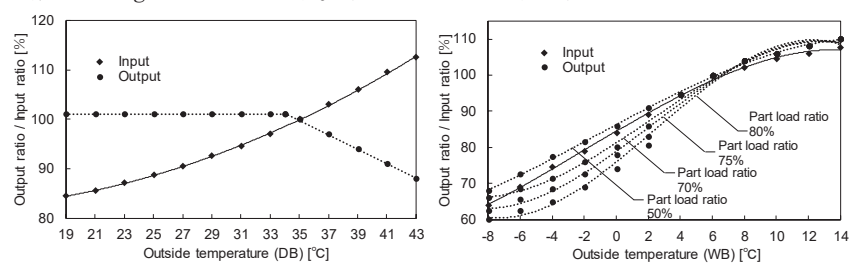

Input

$y=0.0268 x^{2}-0.4822 x+83.889$

Output

$\mathrm{DB} \leqq 34$

$y=101$

$\mathrm{DB}>34$

$y=-1.4658 x+151.11$

Input
$y=-0.0036 x^{3}-0.0205 x^{2}+2.6078 x+84.485$

Output

$50 \%$
$y=-0.0028 x^{3}-0.0095 x^{2}+2.3603 x+86.312$
$70 \%$
$y=-0.0086 x^{3}+0.0568 x^{2}+2.8751 x+81.278$

$y=-0.0086 x^{3}+0.0568 x^{2}+2.8751 x+81.278$
$75 \%$

$y=-0.0103 x^{3}+0.0688 x^{2}+3.1874 x+78.921$

$y=-0.0132 x^{3}+0.0982 x^{2}+3.5338 x+75.974$

Fig.A2 Correction by the outside temperature for Cooling

Fig.A3 Correction by the outside temperature for Heating

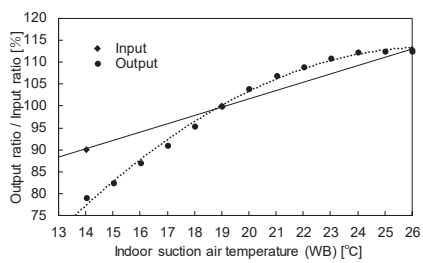

nput

$y=1.9128 x+63.381$

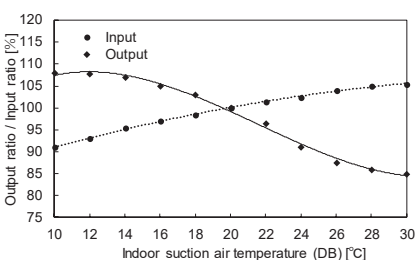

Input

$y=-0.0178 x^{2}+1.4382 x+78.465$

Output

$y=-0.2225 x^{2}+11.9 x-45.644$

Output

$y=0.0069 x^{3}-0.4435 x^{2}+7.6704 x+68.222$

Fig.A4 Correction based on indoor Fig.A5 Correction based on indoor suction air temperature for Cooling suction air temperature for Heating

注 4) EPW の東京 (百里) と NewHASP の東京における外気温の比較を Fig.A6 に示す。百里は東京より外気温が約 $5^{\circ} \mathrm{C}$ 低いため, 暖房負荷が大きく, COP が悪くなり, 暖房エネルギ一使用量が増大し, 冷房負荷が小さく, COP が良 くなり, 冷房エネルギー使用量が減少した。

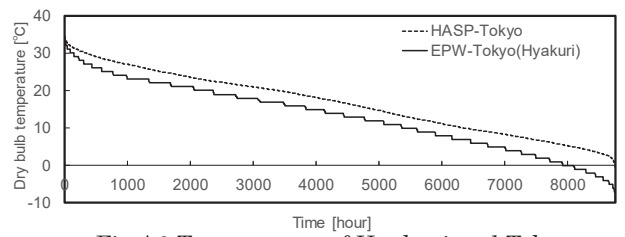

Fig.A6 Temperature of Hyakuri and Tokyo 
注 5）Fig.9, 11 空調エネルギー（冷房）（暖房）と眺望性の関係を Fig.A7 に示 す。常にブラインドを下ろしているため，全体的に遮蔽される割合が高い。

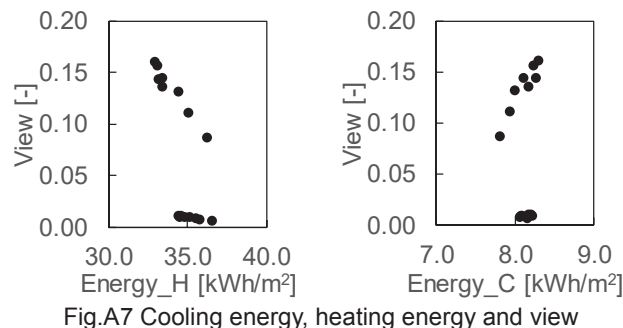

注 6) ブラインド $0^{\circ}$, 垂直ルーバー角度 $0^{\circ}$, 幅 $220 \mathrm{~mm}$, 間隔 $2,000 \mathrm{~mm}$ とし た場合の，本研究での眺望性の評価点（空面から室内側に $2 \mathrm{~m}$ ）および室内 側に $4 \mathrm{~m}, 6 \mathrm{~m} ， 7.5 \mathrm{~m}$ の視点位置における天空，地面，天井，壁，床，ルー バー，ブラインドが見える割合を円グラフに示す。空面から $6 \mathrm{~m}$ までの視点 からは，天空と地面が見えている

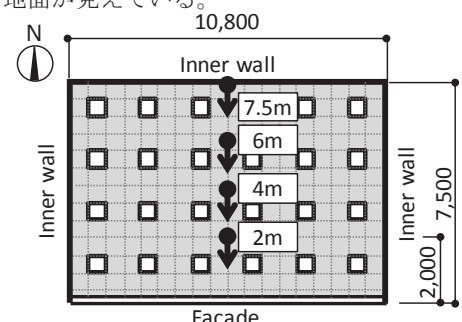

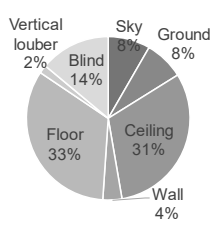

$2 \mathrm{~m}$
Blind Sky

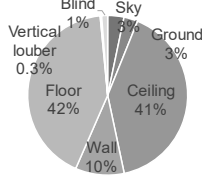

$6 \mathrm{~m}$

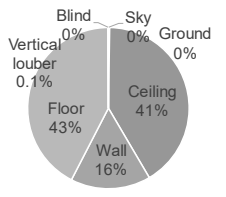

$7.5 \mathrm{~m}$
Fig.A8 Ratio of view

\section{参考文献}

1) Daylight in buildings; English version EN 17037:2018, English tran slation of DIN EN 17037:2019-03, 2019.3

2) Radiance : https://www.radiance-online.org/about/main.html, accessed 2019.5.8

3) Nagai, T., Ohga, H., : Features and User's Guide of New HASP/ACLD-8, Proseedings of SHASE Symposium 'The Present and the Future of Software for Thermal Load and HVAC, SHASE, 2004

長井達夫，相賀洋 : NewHASP/ACLD-Bの特徴と利用法, 空気調和・衛生工 学会シンポジウム 熱負荷・空調ソフトウェアの現状と将来, 2004

4) Kohri, K.and Ishino, H. : A PRACTICAL CALUCULATION METHOD OF SOLAR SHADING PERFORMANCE CHANGES A study on performance values of windows for thermal load caluculation Part 2, Journal of Environmental Engineering (Transactions of AIJ), Vol.77, No.672, pp.89-93, 2012.2(in Japanese)

郡公子, 石野久彌：一般空の日射遮蔽性能変動の実用的推定法 熱負荷計 算のための空性能值に関する研究 第2報, 日本建築学会環境系論文集, 第 77巻, 第672号, pp89-93, 2012.2

5) Yoshizawa, N., Takeda, H., Kondo, J., : THERMAL LOAD CALCULATION METHOD CONSIDERING INDIRECT ANGLE CHARACTERISTICS OF SUN SHADES Radiance application for optical properties calculations of inner blinds, Journal of Environmental Engineering (Transactions of AIJ), Vol.74, No.640, pp.675-683, 2009.1(in Japanese)

吉澤望, 武田仁, 近藤純一：日射遮蔽物の入射角特性を考慮した熱負荷計 算 内付けブラインドの光学特性計算への Radiance の適用, 日本建築学会 環境系論文集，第 74 巻，第 640 号, pp675-683, 2009.1

6) Takeda, H., Suzuki, H., Hayakawa, S., : THERMAL CHARACTERISTICS OF AN OPENING WITH SOLAR RADIATION SHADING Evaluation of optical characteristics on a venetian blind and thermal characteristics regarding an air space, Journal of Environmental Engineering (Transactions of AIJ), Vol.79, No.706, pp.1037-1047, 2014.1(in Japanese)

武田仁, 鈴木宏和, 早川眞：開口部の日射遮蔽物による熱特性 ベネシャ ンブラインドの光学特性および中空層の熱特性の検証, 日本建築学会環境 系論文集，第79巻，第706号, pp1037-1047, 2014.1

7) Takeda, H., Inanuma, M., Yoshizawa, N., Isozaki, K., : Standard weather data and thermal load calculation program LESCOM : Inouesyoin, 2005 武田仁, 稲沼實, 吉澤望, 磯崎恭一郎 : 標準気象データと熱負荷計算プログ ラムLESCOM, 井上書院, 2005

8) Ohki, C., Okamoto, T., Ohga, H., Yoshizawa, N., : ENERGY PERFORMANCE EVALUATION OF OUTSIDE SUN SHADINGS USING RADIANCE AND NEWHASP, Journal of Environmental Engineering (Transactions of AIJ), Vol.83, No.753, pp.861-870, 2018.11(in Japanese)

大木知佳子，岡本俊英，相賀洋，吉澤望：RadianceとNewHASPを用いた 外部日射遮蔽物のエネルギー性能評価, 日本建築学会環境系論文集, 第83 巻, 第753号, pp. 861-870, 2018.11

9) Lee, E.S., Geisler-Moroder, D. and Ward G, : Modeling the direct sun component in buildings using matrix algebraic approaches: Methods and validation, Solar Enregy, Vol.160, pp.380-395, 2018

10) Manzan, M. and Pinto, F, : GENETIC OPTIMIZATION OF EXTERNAL SHADING DEVICES, Proceedings of BS2009, 11th International IBPSA Conference, 2009Glasgow, Scotland, pp.180-187, 2009.7

11) Atzeri, A., Cappelletti, F. and Gasparella, A, : Internal Versus External Shading Devices Performance in Office Buildings, ScienceDirect, Energy Procedia 45, pp463-472, 2014

12) Konta, M., Shao, Q., Yamada, H. and Kobayashi, H, : Evolutionary Optimization of the Top-Lighting Systems using algorithm editor based on the Annual Simulation, Summaries of Technical Papers of Annual Meeting, Architectural Institute of Japan, Environmental EngineeringI, pp. 529-530, 2018.7

今田莱莉奈，邵琪，山田浩嗣，小林光：アルゴリズムエディタを用いた年 間評価に基づくトップライトシステムデザインの進化的最適化に関する研 究, 日本建築学会大会学術講演梗概集, 環境工学-I, pp. 529-530, 2018.7

13) Wada, M. and Nakaohkubo, K, : Shape optimization of slats of Louver using Multi objective Genetic Algorithm, Summaries of Technical Papers of Annual Meeting, Architectural Institute of Japan, Environmental Engineering-I, pp. 531-532, 2018.7

和田基, 中大窪千晶：多目的遺伝的アルゴリズムを用いたスラットの形状 操作に基づく夏季の南面設置型ルーバーの最適化, 日本建築学会大会学術 講演梗概集, 環境工学-I, pp. 531-532, 2018.7

14) Ohki, T. et al.: Shape Optimization of Vertical Louvers for the West Facade Part1. Optimum Solution Focused on Sunlight Shading using Parametric Study Method, Summaries of Technical Papers of Annual Meeting, Architectural Institute of Japan, Environmental EngineeringI, pp. 1101-1102, 2018.7

大木泰祐, 佐藤大樹, 高取昭浩：西面ファサードの縦ルーバーを対象とし た形状最適化 その 1 パラメトリックスタディによる日射遮蔽に着目した 最適解, 日本建築学会大会学術講演梗概集, 環境工学-I, pp. 1101-1102, 2018.7

15) Sato, T. et al.: Shape Optimization of Vertical Louvers for the West Facade Part2. Multi-Objective Optimization using Genetic Algorithm, Summaries of Technical Papers of Annual Meeting, Architectural Institute of Japan, Environmental Engineering-I, pp. 1103-1104, 2018.7 佐藤大樹, 大木泰祐, 高取昭浩：西面ファサードの縦ルーバーを対象とし た形状最適化 その 2 遺伝的アルゴリズムを用いた多目的最適化, 日本建 築学会大会学術講演梗概集, 環境工学-I, pp. 1103-1104, 2018.7

16) Harada, N. and Tanabe, S, : Proposal of New Daylighting Façade for School Classroom Using Parametric Design, Technical Papers of Annual Meeting, Vol.10, E-66, 2015

原田尚侑, 田辺新一：パラメトリックデザインを用いた学校教室の新しい 昼光利用型ファサードの提案，空気調和・衛生工学会大会学術講演論文集， 第 10 巻, E-66, 2015

17) Ohki, C., Okamoto, T., Ohga, H., Yoshizawa, N., Aizawa, N., : Study on annual evaluation of light and thermal environment performance of 
exterior and interior sun shadings Summaries of Technical Papers of Annual Meeting, Architectural Institute of Japan, Environmental Engineering-I, pp. 585-586, 2019.7

大木知佳子, 吉澤望, 相賀洋, 相沢則夫 : 外部 -内部日射遮蔽物の光・熱環 境性能年間評価に関する研究, 日本建築学会大会学術講演梗概集, 環境工 学-I, pp. 585-586, 2019.7

18) Ohki, C., Okamoto, T., Tadaki, J., Ohga, H., Yoshizawa, N., : FAÇADE DESIGN OPTIMIZATION BASED ON ENERGY USAGE, GLARE, AND VIEW USING RADIANCE AND NEWHASP, CIE ( International Commission on Illumination) 2019 29TH Quadrennial Session at Washington, 2019

19) EnergyPlus Weather data : https://energyplus.net/weather, accessed 2019.3.30

20) Yoshizawa, N., Miki, Y., Yamaguchi, H., Tamura, H., : SYSTEMATIC EVALUATION ON DAYLIGHT HARVESTING ENERGY-SAVING EFFECTS IN OFFICES, Journal of Environmental Engineering (Transactions of AIJ), Vol.83, No.747, pp.425-434, 2018.5(in Japanese) 吉澤望，三木保弘，山口秀樹 田村仁人 : 昼光利用によるオフィスの照明 エネルギー削減効果の系統的検討 東京圈の年間標準気象データを用いた シミュレーションによる検討, 日本建築学会環境系論文集, 第 83 巻, 第 747 号, pp425-434, 2018.5

21) Architectural Institute of Japan: Architectural Institute of Japan Environmental Standards AIJES-L0003-2018 Standards for Daylighting, 2018 (in Japanese)

日本建築学会: 日本建築学会環境規準AIJES-L0003-2018昼光照明規準・同 解説, 2018

22) Wienold, J, : DYNAMIC DAYLIGHT GLARE EVALUATION, Proceedings of BS2009, 11th International IBPSA Conference, 2009Glasgow, Scotland, pp.944-951, 2009.7

23) Ohga, H., Yoshizawa, N., Ohki, C., Aizawa, N., : NewHASP-Based MetaSimulation Part3 Basic Meta-Simulation of Lighting, Summaries of Technical Papers of Annual Meeting, Architectural Institute of Japan, Environmental Engineering-II, pp. 1351-1354, 2017.7 相賀洋，吉澤望，大木知佳子, 相沢則夫：NewHASP を核としたメタシミ ユレーション技術に関する研究 第 3 報 昼光利用メタシミュレーションモ デル, 日本建築学会大会学術講演梗概集, 環境工学-II, pp. 1351-1354, 2017.7

24) Ohga, H, : NewHASP-Based Meta-Simulation Part1 Basic Design of NewHASP-Based Meta-Simulation, Summaries of Technical Papers of Annual Meeting, Architectural Institute of Japan, Environmental Engineering-II, pp. 31-32, 2016.7

相賀洋 : NewHASP を核としたメタシミュレーション技術に関する研究 第 1 報 メタシミュレーションモデルの基本設計, 日本建築学会大会学術講 演梗概集，環境工学-II, pp. 31-32, 2016.7

25) Ohki, C., Yoshizawa, N., Ohga, H., Aizawa, N., :Annual environmental performance evaluation of light and heat in daylight harvesting systems, Summaries of Technical Papers of Annual Meeting, Architectural Institute of Japan, Environmental Engineering-I, pp. 439-442, 2017.7 大小知佳子, 吉澤望, 相賀洋, 相沢則夫 : 昼光利用システムの光・熱環境性 能の年間評価に関する研究, 日本建築学会大会学術講演梗概集, 環境工学I, pp. 439-442, 2017.7

26) Ohga, H., Yoshizawa, N., Aizawa, N., : NewHASP-Based MetaSimulation Part4 Coupled Meta-Simulation Model of Daylight Harvesting System \& Multi-Split Air-Conditioning System, Technical Papers of Annual Meeting, Vol.5, H-20, 2017

相賀洋, 吉澤望, 相沢則夫：NewHASP を核としたメタシミュレーション 技術に関する研究 第 4 報 昼光利用システムと個別分散空調システムの複 合メタシミュレーションモデル, 空気調和・衛生工学会大会学術講演論文集, 第 5 巻, H-20, 2017

27) Building Equipment Design Standards 2015 Edition, Ministry of Land, Infrastructure, Transport and Tourism Minister's Secretariat Government Office Administration Department, Facilities and Environment Division, Public Architectural Institute of Japan, pp. 428, 2015.8.30 建築設備設計基準平成 27 年度版, 国土交通省大臣官房官庁営繥部設備 ・ 環境課, 一般社団法人公共建築協会, pp.428, 2015.8.30
28) Grasshopper algorithmic modeling for Rhino : https://www.grasshopper3d.com/, accessed 2019.3.30

29) OCTOPUS : https://www.food4rhino.com/app/octopus, accessed 2019.3.30

30) ETH Zurich : https://sop.tik.ee.ethz.ch/pisa/, accessed 2019.4.16

31) Sato, H., Ishibuchi, H., : Current status and subjects of evolutionary many-objective optimization, Communications of the Operations Research Society of Japan, Vol.62, No 3, pp.156-163, 2018.3 佐藤寛之, 石渕久生, : 進化型多数目的最適化の現状と課題, 機関誌オペレ ーションズ・リサーチ, 第 62 巻, 第 3 号, pp.156-163, 2018.3 


\title{
OPTIMIZATION OF OUTSIDE AND INSIDE SUN SHADING DEVICES USING RADIANCE AND NEWHASP
}

Pareto optimal solution by energy usage, glare and view

\author{
Chikako OHKI ${ }^{* 1}$, Toshihide OKAMOTO ${ }^{* 2}$, Jyurie TADAKI ${ }^{* 2}$, \\ Tatsuya YAMAMOTO*2, Hiroshi OHGA*3 and Nozomu YOSHIZAWA*4 \\ *1 Obayashi Corporation / \\ Grad. Student, Dept. of Architecture, Tokyo University of Science \\ ${ }^{* 2}$ Grad. Student, Dept. of Architecture, Tokyo University of Science \\ *3 Obayashi Corporation, Dr.Eng. \\ ${ }^{* 4}$ Prof., Dept. of Architecture, Tokyo University of Science, Dr.Eng.
}

Daylight harvesting is now attracting attention not only from energy saving but also from the viewpoint of improving the health and comfort of people working in the building. Daylighting standards, such as EN 17037:2018, provides the target values to obtain sufficient daylight, and also prescribe the evaluation criteria for view and glare.

We used a Meta_Simulation platform that combined Radiance and NewHASP to evaluate lighting and air conditioning energy of exterior and interior sun shading devices. We confirmed the behaviour of basic parameters by combining glare and view evaluations from Radiance and using the graphical algorithm editor Grasshopper to calculate air conditioning/lighting energy, glare index and view. By utilizing the plug-in software OCTOPUS, we evaluated air conditioning/lighting energy usage, glare, and view based on four variables of exterior and interior sun shading devices and the optimal solution for Tokyo (Hyakuri) was confirmed.

For glare, the vertical illuminance of the viewpoint was not high in the building targeted by our simulation, and because no cases exceeded the allowable simplified DGP value of 0.35 , the threshold was lowered to evaluate glare in the multi-objective optimization calculation.

Under the European Standard, view is evaluated based upon the horizontal angle of the window, the distance to adjacent buildings, and the number of layers for sky, landscape, and ground that can be seen (European committee for standardization, 2019). We used a simple evaluation based upon the ratio of sky that could be seen from a sample point, however it is possible to incorporate the view metrics of the EN 17037:2018 into our new module using Radiance.

We conducted a multi-objective optimization calculation for the annual fixed angle of vertical louvers and of blinds typically used in the sun shading devices. In the future, we plan to apply optimization calculations to complex sun shading devices such as slat cut-off angle controls for blinds, moveable or curved surfaces for exterior sun shading. 